Received: 27/06/2018

Revision: 26/11/2018

Accepted: 01/12/2018

OnlineFirst: 21/01/2019

\title{
The Effect of School Leaders' Authentic Leadership on Teachers' Job Stress in the Eastern part of Peninsular Malaysia
}

\section{Siti Noor Ismail}

AP, School of Education, Universiti Utara Malaysia, 06010 Sintok, Kedah, Malaysi, siti.noor@uum.edu.my

Anis Salwa Abdullah

Dr., EPRD, Malaysia Education Ministry, Malaysia, anis_salwa@ahsgs-uum.edu.my

\section{Abdul Ghani Kanesan Abdullah}

Prof., School of Education, Universiti Sains Malaysia, Penang, Malaysia, agk@usm.edu.gov

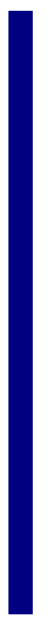

This study was conducted to determine the relationship and the effect of school leaders' authentic leadership towards teachers' job stress. A cross-sectional quantitative approach using a questionnaire has been used on 330 teachers from 143 excellent performance primary schools in the Eastern part of Peninsular Malaysia. Authentic Leadership Questionnaire instrument (ALQ) was adopted from Walumbwa et al., (2008) and Teachers' Work Stress instrument (TWS) by Collie et al. (2012) and Boyle, Borg, Falzon, \& Jr. (1995) was used to obtain the data. Descriptive statistical analysis shows that the level of authentic leadership among the leaders is high and the level of teachers' job stress is. The finding also revealed that there is a moderate negative significant relationship between school leaders' authentic leadership and teachers' job stress. Furthermore, Stepwise's multiple regression analysis shows that authentic leadership also contributed a significant negative impact on teachers' job stress. This study recommends that school leaders adopt authentic leadership in their practices to improve and manage teachers' job stress which in turn will help to improve school excellence, especially across the current era of globalization.

Keywords: authentic leadership, job stress, school leaders, excellent performance primary schools

\section{INTRODUCTION}

Organizational behavioural studies manage to help the organizations through various aspects, including behaviour within the organization and relationships related to other 
organizations. Organizational behaviour consists of two (2) categories, namely microorganizational behaviour and macro-organizational behaviour. The behaviour of microorganizations refers to individuals and groups that are dynamic in an organization's atmosphere. While the macro-organizational behaviour theory examines the entire organization and industry, including how to adjust, as well as strategies, structures, and contingencies that guides human resources. The concepts such as leadership, decisionmaking, teamwork development, motivation, job satisfaction and stress are among the subset of organizational behaviour and management responsibilities. Organizational behaviour also has a strong effect on cultures that are extremely closely related to how the members act (Cole, 2005).

In Malaysia, a study by the National Union of the Teaching Profession (NUTP) found that $70 \%$ of 9,000 teachers throughout Malaysia experienced work pressure. Apart from the burden of increasingly complex tasks, teachers are depressed because they have to face the headaches of the principals, clerks, parents and students (Siti Nor Afzan, 2009). Teachers in primary schools are experiencing job stress, most of all due to student misconduct. In addition, teacher's mental well-being is also influenced by the burden of duty and gender. Women teachers with a heavy burden of duty were found to have lower mental health status (Nurul Izzah Abdul Samad \& Zailina Hashim, 2010; Klassen, 2010). Indeed, the factor of student misconduct is a major factor that causes teacher's work pressure and is followed by task load (Collie, Shapka, \& Perry, 2012; Ferguson et al., 2012), time constraints and resources; rewards (Saad et al., 2012) and interpersonal relationship (Hong \& Aziah Ismail, 2015). If the factors contributing to teacher pressure and burnout (Steinhardt, Jaggars, Faulk, \& Gloria, 2011) are not being dealt with immediately, serious negative impacts can occur and teachers will be more susceptible to much stress-related work, which in turn results in teachers being unable to deliver quality education to students (Pheng, 2015).

In this regard, principal leadership is said to be able to determine the pattern of a school, the learning climate, the level of professionalism and morals of the teachers and the level of concern for pupil inequality (Agezo, 2010). Leadership impact is believed to influence changes in school academic achievement through its impact on teachers, teaching quality as well as school climate and culture (Sammons, Gu, Day, \& Ko, 2011). But which leadership style can reduce teachers' work pressure? The authentic style of leadership is believed to have a positive impact on teachers because leaders who practice this style always express themselves in an open and honest way, which will lead to positive and ethical work (Banks, McCauley, Gardner, \& Guler, 2016). Authentic leadership inspires and promotes positive psychological capabilities, focusing on the perspective of moral and ethical behaviour, as well as maintaining transparency and honesty in relation to workers. So basically, authentic leadership is a new leadership construct that has been empirically attracted in an attempt to overcome the crisis of confidence among the leaders (Gardner, Cogliser, Davis, \& Dickens, 2011) and can help solve the stress problem of teachers. But to what extent does this authentic leadership style affect the stress level of the teachers? 
Hence, the purpose of this study is to identify the level of authentic leadership of the headmaster, the level of stress among teachers, to see the difference in the level of teacher stress based on demographic factors, to identify the relationship between authentic leadership and job stress, as well as the effect of authentic leadership on job stress.

\section{REVIEW OF LITERATURE}

\section{Authentic Leadership}

Authentic leadership is a leadership style that is conceptually new in education (Bird, Wang, Watson, \& Murray, 2012), which includes ethical values and behaviours (Yukl, Mahsud, Hassan, Prussia, \& Prussia, 2013). As a new construct, this authentic leadership is still in development stage, and it is expected that the emergence of various views and perspectives on this leadership are still in progress (Klenke, 2007).

Research by Arif Hassan and Forbis Ahmed (2011) also support authentic leadership theory and mentioned that the real leader establishes a reliable relationship with his staff, and his subordinates are happy to work in such organizations. An organization that has been identified as a great workplace, will locate and emphasis on the quality of a relationship between the employees with their leader, between the employees with their duties and responsibilities, as well as among their fellow workers.

This authentic leadership is in the behavioural leadership form that develops positive psychological capacity and ethical climate, in order to foster higher self-awareness, moral perspective, balanced information processing and transparency of working relationships between leaders and followers, who can improve the positive selfdevelopment (Walumbwa, Avolio, Gardner, \& Peterson, 2008), thereby controlling and reducing the negative factors that may exist.

\section{Job Stress}

Stress is one of the factors that have a negative impact on teachers that will affect the achievement of students (Alyas Qadeer Tahir, 2011; Ashikia, 2010). In addition, the role of teachers and school leaders is very complex and multi-dimensional. Besides, work performance is influenced by several factors including creating and maintaining a healthy and creative working environment. Effective and systematic career training and development opportunities, teacher engagement in decision-making and better working conditions are factors that help teachers work, improve job satisfaction and reduce emotional stress (Anastasiou \& Papakonstantinou, 2014).

Among the factors that influence and are the main predictors in the teachers' job stress in school are students disruptive behaviour that contribute to the highest correlation value (Karaj, 2012; Schaubman, Stetson, \& Plog, 2011; Boyle, Borg, Falzon, \& Jr., 1995), time and workloads pressures (Boyle et al., 1995), and also the relationships with school administrators, but do not include relationships between colleagues (Karaj, 2012). Thus, in the teaching profession, stress is also considered as an influential factor that affects teacher performance (Tahir, 2011). 


\section{Research Questions}

The following research questions were developed for this study:

1. What is the level of school leaders' authentic leadership and teachers' job stress?

2. Is there any significant difference on teachers' job stress based on demographic factors (gender and age)?

3. Is there any significant relationship between school leaders' authentic leadership and teachers' job stress?

4. Is school leaders' authentic leadership affects to the teachers' job stress?

\section{METHOD}

\section{Research Design}

This cross-sectional study examined the relationship between the school leaders' authentic leadership and teachers' job stress for the population of teachers in excellent performance primary schools in the Eastern part of Peninsular Malaysia. All these schools were in Score 4 in Malaysia Education Quality Standard with school average grade (GPS) for the examination in Primary School Achievement Test.

The research design adopted for this study was descriptive survey of the correlational and multiple regression method. According to Patton (2002), data obtained from quantitative methodology is systematic, uniform and easy to be presented. Descriptive statistics was used to examine the level of school leaders' authentic leadership and teachers' job stress. Furthermore, inferential statistics (correlation coefficient) was used to examine the relationship between the variables. Correlational design is appropriate for measuring such complexities of the pattern of relationships that exists among measured variables (Stangor, 2004). Furthermore, the multiple regression method is used to examine the effect of school leaders' authentic leadership on teachers' job stress.

\section{Respondents}

The target population for this study comprised all teachers from UPSR excellent performance primary schools in the Eastern part of Malaysia. The respondents were screened through the stratified sampling method in order to group the population into the homogeneous stratum. A total of 330 teachers were selected as respondents among the teachers in those primary schools by using the simple random method.

The age and gender demographic factors are highlighted in this study as surveys made on past studies show that both age factors (Bertolino, Truxillo, \& Fraccaroli, 2011; Steven, William, \& Chet, 2012; Innocenti, Profili, \& Sammarra, 2013; Zacher \& Griffin, 2015; Simons, Peeters, Janssens, Lataster, \& Jacobs, 2016; Maksymilian, Popiel, Zawadzki, \& Sedek, 2017; Quttainah, 2015) and gender (Wang \& Miao, 2012; Bellman, Forster, Still, \& Cooper, 2003; Miao \& Kim, 2009; Shabani \& Damavandi, 2011; Teoh, Chong, Yip, Lee, \& Wong, 2015; Bremer-Landau, 2014; Kumar, Channa \& Bhutto, 
2017; Quttainah, 2015) contributed to the study variables reviewed, which function as moderator variables.

\section{Instruments}

The main instruments that measured the authentic leadership constructs was Authentic Leadership Questionnaire instrument (ALQ) by Walumbwa et al., (2008) while teachers' job stress was measured using Teachers Work Stress instrument (TWS) by Collie et al. (2012) and Boyle, Borg, Falzon, and Jr., (1995). The ALQ original scale was measured by 16 items while TWS contained 24 items. All scales were then translated and adapted before being used in this study. The pilot study was conducted using the instrument with 10-points interval scale ranging from 1 (Strongly Disagree) to 10 (Strongly Agree). Then, the exploratory factor analysis (EFA) was performed. The construct of authentic leadership formed three (3) components with 16 items, while job stress formed eight (8) components respectively, all by maintaining the original numbers of items. The values of the reliability of authentic leadership $(\alpha=.91)$ were considerably high while job stress $(\alpha=.68)$ was moderate and reasonable (Taber, 2017; Hinton, McMurray, Brownlow, \& Cozens, 2004).

\section{Data Analysis}

Data analysis techniques used a descriptive statistical analysis and inferential statistical analysis. The descriptive statistical analysis was used to describe the profile of respondents and mean score for the level of authentic leadership and the level of teachers' job stress. While the inferential statistical analysis was used to analyze the relationship between school leaders' authentic leadership and teachers' job stress. Furthermore, the multiple regression method was used to examine the effect of school leaders' authentic leadership on teachers' job stress. The data of this research were analyzed using the SPSS program version 25 and test of 0.05 significance level. Before analyzing the data, screening and selection had to be applied in order to ensure the quality of research data by excluding the respondents who did not give full cooperation in responding the questionnaires, as well as not reading and understanding the questionnaire items well before answering (Othman Talib, 2015; Zainudin Awang, 2014).

\section{FINDINGS}

\section{Descriptive Analysis}

The respondents of this study consisted of 206 female teachers $(62.4 \%)$ and 124 male teachers $(37.6 \%)$. For the age group of 40 to 49 years old, there were 125 teachers (37.90\%), followed by $122(37.0 \%)$ teachers in the age group of 30 to 39 years old. While the other 66 teachers were in the age group of 50 years old and above $(20.00 \%)$ and $17(5.1 \%)$ teachers were in the age group of below 30 years old. The total number of respondents involve was 330 teachers, as explained in Table 1: 
Table 1

Demographic analysis of respondents $(\mathrm{N}=330)$

\begin{tabular}{llll}
\hline & Demographic & Frequency & $\%$ \\
\hline Gender & & & \\
& Male & 124 & 37.60 \\
& Female & 206 & 62.40 \\
\hline Age & & & \\
& Below 30 years old & 17 & 5.1 \\
& 30-39 years old & 122 & 37.0 \\
& 40-49 years old & 125 & 37.9 \\
& 50 years old and above & 66 & 20.0 \\
\hline
\end{tabular}

\section{Authentic Leadership and Job Stress Level}

Mean interpretation is classified into three (3) categories which are low (1.00-2.33), moderate (2.34-3.67) and high (3.68-5.00) (Mohd Hasril Amiruddin, Isma Atiqah Ngadiran, Fathin Liyana Zainudin, \& Norhayati Ngadiman, 2016). However, since the scale range for this study is 10 points, the mean interpretation is modified to obtain the more accurate interpretation. The interpretations used in this study are very low $(0.00$ 1.99), low (2.00-3.99), moderate (4.00-5.99), high (6.00-7.99) and very high (8.0010.00).

The authentic leadership construct consists of three (3) components, namely selfawareness and transparency relationship (AL1), internal moral perspective (AL2) and balanced process (AL3). All the components in this construct are at high levels. The AL3 component has the highest mean value $(\mathrm{M}=7.35 ; \mathrm{SD}=2.19)$ compared to two (2) other components respectively AL1 (M=7.30; SD=2.08) and AL2 (M=7.22; SD=2.09), explained in the following Table 2:

Table 2

Mean and standard deviation of authentic leadership construct

\begin{tabular}{llll}
\hline \multicolumn{1}{c}{ Authentic leadership } & Mean & Standard Deviation & Level \\
\hline AL3 Balanced process & 7.35 & 2.19 & High \\
AL1 Self-awareness and transparency relationship & 7.30 & 2.08 & High \\
AL2 Internal moral perspective & 7.22 & 2.09 & High \\
\hline Overall Mean Score & 7.29 & 1.96 & High \\
\hline
\end{tabular}

(Source: Modified from Mohd Hasril Amiruddin et al., 2016)

While for job stress construct, the data from 330 respondents in this study showed that the most significant aspects of teachers' job stress was the JS6 component, which is training and support $(\mathrm{M}=3.78 ; \mathrm{SD}=1.50), \mathrm{JS} 8$ for technology literacy $(\mathrm{M}=3.64$; $\mathrm{SD}=1.79)$ and JS7 for facilities and curriculum exposure constraints $(\mathrm{M}=3.43$; $\mathrm{SP}=1.49$ ). This suggests that teachers in schools consider lack of training and support, as well as incompetence of technology as the contributor to job stress.

The next component is JS1 which is students' misbehaviours $(\mathrm{M}=3.32 ; \mathrm{SD}=2.08)$, JS2 for workloads $(\mathrm{M}=3.28 ; \mathrm{SD}=1.82)$ and JS5 for interpersonal relationship $(\mathrm{M}=3.17$; $\mathrm{SP}=1.57)$. The JS4 component of time and resources constraints is the component that 
gives the lowest contribution to teachers' job stress with the value $(\mathrm{M}=3.06 ; \mathrm{SD}=1.62)$ followed by $\mathrm{T} 3$ of professional recognition $(\mathrm{M}=3.09 ; \mathrm{SD}=1.70)$, shown in Table 3:

Table 3

Mean and standard deviation of job stress construct

\begin{tabular}{llll}
\multicolumn{1}{c}{ Job stress } & Mean & Standard Deviation & Level \\
\hline JS6 Training and support & 3.78 & 1.50 & Low \\
JS8 Technology literacy & 3.64 & 1.79 & Low \\
JS7 Facilities and curriculum exposure constraints & 3.43 & 1.49 & Low \\
JS1 Students misbehaviours & 3.32 & 2.08 & Low \\
JS2 Workloads & 3.28 & 1.82 & Low \\
JS5 Interpersonal relationship & 3.17 & 1.57 & Low \\
JS3 Professional recognition & 3.09 & 1.70 & Low \\
JS4 Time and resources constraints & 3.06 & 1.62 & Low \\
\hline Overall Mean Score & 3.35 & 1.43 & Low \\
\hline
\end{tabular}

(Source: Modified from Mohd Hasril Amiruddin et al., 2016)

\section{Job Stress Difference based on Demographic Factors (Gender and Age)}

The t-test shows that the value of $\mathrm{t}(328)=3.66, \mathrm{p}<.01$ for the level of job stress based on gender is significant. This means there is significant difference in the level of job stress between male and female teachers. The mean of male teachers' job stress $(M=3.71, S D=1.48)$ is higher than the mean of female teachers' job stress $(M=3.13$, $\mathrm{SD}=1.36$ ). The Levene test gave a non-significant value, $\mathrm{p}>.05$, which shows that both gender groups had the same variance scores. The t-test analysis shows that male teachers' job stress is higher than female teachers, as shown in Table 4 below:

Table 4

The t-test analysis for the job stress difference based on gender

\begin{tabular}{ccccll}
\hline & $\mathrm{N}$ & Mean & Standard Deviation & $\mathrm{t}$ & $\mathrm{df}$ \\
\hline Gender & & & & $3.66^{* *}$ & 328 \\
Male & 124 & 3.71 & 1.48 & & \\
Female & 206 & 3.12 & 1.36 & & \\
\hline
\end{tabular}

***Correlation is significant at the 0.01 level (2-tailed)

The one-way ANOVA test shows the value of $F(3,326)=3.49$, with the value of $p<.05$ for teachers' job stress level based on age is significant. Therefore, there is a difference in the level of teacher's job stress based on age groups, as in the following Table 5:

Table 5

The ANOVA analysis for the job stress difference based on age

\begin{tabular}{|c|c|c|c|c|c|}
\hline & $\mathrm{N}$ & Mean & Standard Deviation & $\mathrm{F}$ & $\mathrm{df}$ \\
\hline Age & & & & $3.49 * *$ & 3,326 \\
\hline Below 30 years old & 17 & 2.93 & 1.22 & & \\
\hline $30-39$ years old & 122 & 3.07 & 1.21 & & \\
\hline $40-49$ years old & 125 & 3.59 & 1.58 & & \\
\hline 50 years old and above & 66 & 3.50 & 1.48 & & \\
\hline
\end{tabular}


Table 5 shows that the group of teachers aged between 40 to 49 years old has the highest job stress level $(\mathrm{M}=3.59 ; \mathrm{SD}=1.58)$, followed by teachers aged between 50 years old and above $(\mathrm{M}=3.50 ; \mathrm{SD}=1.48)$ and teachers aged between 30 to 39 years old $(\mathrm{M}=3.07$; $\mathrm{SD}=1.22$ ). While teachers below 30 years old respond that their job stress experience is low ( $\mathrm{M}=2.93 ; \mathrm{SD}=1.22)$.

Given that the ANOVA test for the difference between the teacher's job stress was significant, the Post-Hoc Bonferroni test was performed. This test is used when the Levene test is not significant. The test shows that there is significant difference in the level of teachers' job stress between the age group of 30 to 39 years old and the age group of 40 to 49 years old $(\mathrm{p}<.05)$, with the higher score of age group of 40 to 49 years old $(\mathrm{M}=3.59 ; \mathrm{SD}=1.58)$ compared to the age group of 30 to 39 years old $(\mathrm{M}=3.07$, $\mathrm{SD}=1.21)$.

\section{The Relationship and Effect of Authentic Leadership and Job Stress}

Figure 1 shows the measure of strength and the linkage between the two (2) constructs, which is the correlation of the relationship between the authentic leadership and the job stress.

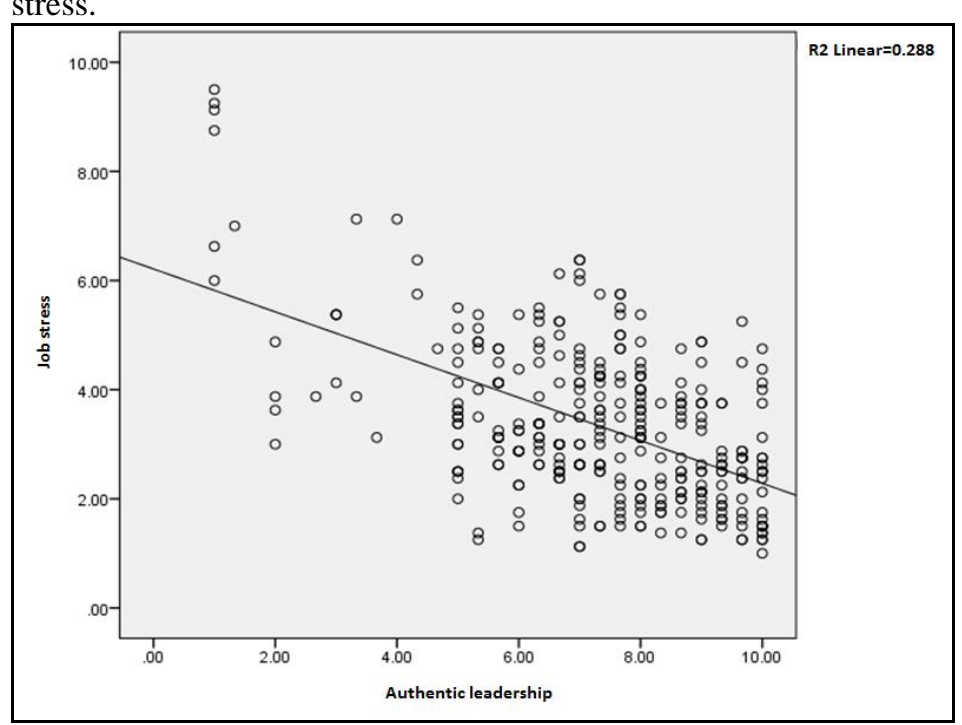

Figure 1

Scatterplot graph for the authentic leadership and job stress scores distribution

The value of $\mathrm{R}^{2}=.288$ on the graph in Figure 1 indicates $28.8 \%$ of the authentic leadership score that contributes directly to the change of job stress scores and this relationship is seen as linear, thus the Pearson correlation parametric statistic is implemented. Table 6 shows a correlation output between the authentic leadership and the job stress constructs. Pearson correlation coefficient value, $r=-.536, n=330, p<.001$ indicates a significant, moderate negative relationship (Dancey \& Reidy, 2011) between authentic leadership and job stress. 
Table 6

Correlation output between the authentic leadership costruct and job stress scores

\begin{tabular}{llll}
\hline & & Authentic Leadership & Job Stress \\
\hline \multirow{3}{*}{ Authentic Leadership } & Pearson Correlation & 1 & $\mathbf{. . 5 3 6}^{* * *}$ \\
& Sig. (2-tailed) & & .000 \\
& $\mathrm{~N}$ & 330 & 330 \\
Job Stress & Pearson Correlation & $\mathbf{- . 5 3 6 * *}$ & 1 \\
& Sig. (2-tailed) & .000 & \\
& $\mathrm{~N}$ & 330 & 330 \\
\hline
\end{tabular}

**Correlation is significant at the 0.01 level (2-tailed).

The three components of the authentic leadership construct consist of AL1 (selfawareness and relationship transparency), AL2 (internal moral perspective), and AL3 (balanced processing). The Pearson correlation analysis shows a correlation coefficient value between the scores for the AL1 component and the job stress is -0.494 (49.4\%), while the correlation coefficient value between the scores for the AL2 component with the job stress is $-0.538(53.8 \%)$. The correlation coefficient value between the scores for the AL3 component with the job stress is -0.456 (45.6\%), as stated in Table 7 . These coefficient values indicate the moderate correlations between the components of the predictor construct of authentic leadership and the dependent variable of job stress.

Table 7

Correlation output between the authentic leadership components and job stress scores

\begin{tabular}{lll}
\hline & & Job Stress \\
\hline & AL1 & $\mathbf{- . 4 9 4 * *}$ \\
& Sig. (2-tailed) & .000 \\
& N & 330 \\
Pearson Correlation & AL2 & $\mathbf{- . 5 3 8 * *}$ \\
& Sig. (2-tailed) & .000 \\
N & 330 \\
& AL3 & $\mathbf{- . 4 5 6 * *}$ \\
& Sig. (2-tailed) & .000 \\
N & 330 \\
\hline
\end{tabular}

The regression model is described through the output in Table 8 . The $\mathrm{R}^{2}$ describes the variance value in the job stress score as the dependent variable associated with the components in the authentic leadership predictor construct is $29.9 \%$. The value of $\mathrm{R}^{2}$ is reported since the sample size is greater than 100, which is $n>100$ (Pallant, 2011).

Table 8

Linear regression output

\begin{tabular}{cllll}
\hline Model & R & R Square & Adjusted R Square & Standard Error of the Estimate \\
\hline 1 & $.547^{\mathrm{a}}$ & .299 & .292 & 1.207 \\
\hline a. Predictors: (Constant), AL3, AL1, AL2 & \\
b. Dependent Variable: Job Stress &
\end{tabular}

The value in ANOVA analysis shows that this model with $\mathrm{R}^{2}=29.9 \%$ is significant, $\mathrm{p}<.05$, as explained in Table 9 . 
Table 9

The ANOVA analysis

\begin{tabular}{lllllll}
\hline & Model & Sum of Squares & df & Mean Square & F & Sig. \\
\hline \multirow{3}{*}{1} & Regression & 202.230 & 3 & 67.410 & 46.286 & $0.00^{\mathrm{b}}$ \\
Residual & 474.783 & 326 & 1.456 & & \\
\hline & Total & 677.013 & 329 & & & \\
\hline
\end{tabular}

a. Dependent Variable: Job Stress; b. Predictors: (Constant), AL3, AL1, AL2

Based on the following Table 10, the contribution of each component for the predictor construct is showed in the standardized coefficients values. The Beta values shown in the standardized coefficients output have been equated with scales as each value is divided by standard deviation value. Beta value shows the contribution of the AL1 component is $-0.129(12.9 \%)$. While the contribution of $-0.377(37.7 \%)$ of the AL2 component significantly affected the job stress score. In addition, the AL3 component contributes $-0.071(7.1 \%)$.

Table 10

The standardized coefficients output

\begin{tabular}{|c|c|c|c|c|c|c|c|}
\hline \multirow[t]{2}{*}{ Model } & \multicolumn{2}{|c|}{$\begin{array}{l}\text { Unstandardized } \\
\text { Coefficients }\end{array}$} & \multirow{2}{*}{$\begin{array}{l}\text { Standardized } \\
\text { Coefficients } \\
\text { Beta }\end{array}$} & \multirow[t]{2}{*}{$\mathrm{t}$} & \multirow[t]{2}{*}{ Significant } & \multicolumn{2}{|c|}{$\begin{array}{l}\text { Collinearity } \\
\text { Statistics }\end{array}$} \\
\hline & $\mathrm{B}$ & Std. Error & & & & Tolerance & VIF \\
\hline \multirow{4}{*}{$\begin{array}{l}\text { AL2 } \\
\text { AL3 } \\
\end{array}$} & 6.202 & 0.257 & & 24.159 & 0.000 & & \\
\hline & -0.089 & 0.060 & -0.129 & -1.493 & 0.137 & 0.286 & 3.491 \\
\hline & -0.258 & 0.062 & -0.377 & -4.158 & 0.000 & 0.262 & 3.814 \\
\hline & -0.046 & 0.050 & -0.071 & -0.932 & 0.352 & 0.374 & 2.674 \\
\hline
\end{tabular}

a. Dependent Variable: Job Stress

The score for the AL2 component $(\beta=-.377, \mathrm{p}<.05)$ is the greatest predictor component which is significant compared to the score for the component AL1 $(\beta=-.129, p>.05)$ and the component AL3 ( $\beta=-.071, \mathrm{p}>.05)$ with the whole $\mathrm{R}^{2}=.299$, which indicates $29.9 \%$.

\section{DISCUSSION AND CONCLUSION}

This study found that the level of school leaders' authentic leadership is high, as perceived by teachers in primary schools. The highest AL3 mean value indicates that the majority of teachers expect their headmasters to have the ability to analyse and take into account the information both from positive and negative aspects before making decisions, as well as specific actions that can affect others by considering the right time to re-evaluate the role of various parties towards important issues at school. While, teachers in schools consider that the lack of training and support, as well as incompetence of technology contribute to job stress, although their level of job stress in school is still low.

Meanwhile, the finding of this study states that there is a significant difference in the level of job stress between male and female teachers. Male teachers' job stress was higher than female teachers. This finding might differ from other previous studies, which stated that the main predictors in the teachers' job stress in school are students' disruptive behaviour (Karaj, 2012; Schaubman, Stetson, \& Plog, 2011; Boyle, Borg, Falzon, \& Jr., 1995), time and workloads pressures (Boyle et al., 1995). 
This finding is different possibly due to the factors that caused the job stress obtained from this study, which found that the most significant factors that cause the job stress among respondents are trainings and supports, technology literacy, as well as facilities and curriculum exposures constraints. This was in line with Hohlfeld, Ritzhaupt, and Barron (2013) that mentioned women had a higher, better factor score in their perception towards technology literacy, thus, men are less likely to be interested in that matter. These findings also support the study of Nurul Izzah Abdul Samad and Zailina Hashim (2010) which explained that gender contributes significantly to teachers' mental health status.

However, their study found that female teachers with heavy workloads had lower mental health and could cause stress. This finding was also unable to support the study by Anastasiou and Papakonstantinou (2014) which explains that women's teachers typically exhibit high levels of stress. In addition, the results of this study were also different from the findings of Azizi Yahaya, Jamaludin Ramli and Mazeni Ismail (2010) which showed that there were no differences between stress factors among male and female teachers.

This study also found that teachers' job stress level based on age was significant; therefore, there is a difference in the level of teacher's job stress based on age groups, with the highest job stress score is from the age group of 40 to 49 years old. Work stress factors in terms of training and support as well as literacy and knowledge on technology might become the barriers to the older teachers, as stated by Urban, Manakova, and Bielcheva (2017) that age is one of the main significant factors contributing to digital literacy, in addition to education, income and household type. This finding is different from the Anastasiou and Papakonstantinou (2014) studies which showed that young teachers were usually more likely to exhibit high levels of stress, as opposed to the results of the study Azizi Yahaya, Jamaludin Ramli and Mazeni Ismail (2010) which found that there was no significant relationship between stress factors and teachers' age.

Finally, the correlation output between the authentic leadership and the job stress constructs value indicates a significant moderate negative relationship. The coefficient values indicate the moderate correlations between the components of the predictor construct of authentic leadership and the dependent variable of job stress. All the three components in the authentic leadership construct contribute and describe more than a quarter of variance of job stress as the dependent construct. The contribution of each component for the predictor construct showed that the internal moral perspective is the greatest predictor component which is significant compared to the score for the component of self-awareness and relationship transparency, and also the balanced processing.

This finding supports Jam et al. (2010) who mentioned that leadership style used by administrators and decreasing power had reduced work pressure among employees in an organization. Negative relationships existed between leadership and job stress. However, Eyal and Roth (2011) in their study stated that the leadership style of the headmaster also became a mastermind for teachers experiencing tiredness at school. In this regard, workload and mobbing disruption at work will lead to stress reactions, 
otherwise, the school leaders' support will reduce perceptions of workload and emotional disturbances (Dick \& Wagner, 2001).

In addition, the confidence of teachers may be able to reduce the negative impact resulting from the pressure faced by teachers (Collie et al., 2012). School administrators who are supportive in providing a positive school climate can create a positive climate. This will encourage teachers, support staff and students to be more committed to the success of schools academic (Mphale, 2015). Indirectly, the controlled teachers' job stress can contribute to academic achievement in schools (Lydiah \& Nasongo, 2009; Hallinger, 2009, 2011a; Rasheed et al., 2010; Alam \& Farid, 2011).

As a conclusion, the future studies may consider the new constructs, whether mediator or moderator constructs, to be included in order to enhance this leadership style to become more effective to manage and control teachers' job stress in schools. These findings contribute to the development of knowledge by confirming that teachers' job stress can be managed through the effectiveness of the authentic leadership practices, thereby supporting the theory of this authentic leadership style.

\section{REFERENCES}

Alam, M. T., \& Farid, S. (2011). Factors affecting teachers motivation. International Journal of Business and Social Science, 2(1), 298-304.

Anastasiou, S., \& Papakonstantinou, G. (2014). Factors affecting job satisfaction, stress and work performance of secondary education teachers in Epirus, NW Greece. International Journal Management in Education, 8(1), 37-53.

Andrews, D., Nonnecke, B., \& Preece, J. (2003). Conducting research on the internet: Online survey design, development and implementation guidelines. International Journal of Human-Computer Interaction, 16(2), 185-210. http://doi.org/10.1207/s15327590ijhc1602_04

Arif Hassan, \& Forbis Ahmed. (2011). Authentic leadership, trust and work engagement. International Journal of Human and Social Sciences, 6(3), 164-170.

Ashikia, O. A. (2010). Students and teachers' perception of the causes of poor academic performance in Ogun State Secondary Schools [Nigeria]: Implications for couselling for national development. European Journal of Social Sciences, 13(2), 229-242.

Azizi Yahaya, Jamaludin Ramli, \& Mazeni Ismail. (2010). Stres dalam kalangan guru sekolah menengah di empat buah negeri di Malaysia. Asia Pacific Journal of Educators and Education, 25, 103-136.

Bird, J. J., Wang, C., Watson, J., \& Murray, L. (2012). Teacher and Principal Perceptions of Authentic Leadership: Implications for Trust, Engagement, and Intention to Return. Journal of School Leadership, 22(3), 425-461.

Boyle, G. J., Borg, M. G., Falzon, J. M., \& Jr., A. J. B. (1995). A structural model of the dimensions of teacher stress. British Journal of Educational Psychology, 65(1), 49-67.

Cole, G. A. (2005). Organisational behaviour (theory and practice) (6th ed.). United Kingdom: Thomson Learning. 
Collie, R. J., Shapka, J. D., \& Perry, N. E. (2012). School climate and social-emotional learning: Predicting teacher stress, job satisfaction, and teaching efficacy. Journal of Educational Psychology, 104(4), 1189-1204. http://doi.org/10.1037/a0029356

Dancey, C., \& Reidy, J. (2011). Statistics without maths for psychology. Book (5th ed.). Rotolito Lombarda, Italy: Prentice Hall.

Dick, R. van, \& Wagner, U. (2001). Stress and strain in teaching: a structural equation approach. British Journal of Educational Psychology, 71, 243-259. http://doi.org/10.1348/000709901158505

Eyal, O., \& Roth, G. (2011). Principals' leadership and teachers' motivation: selfdetermination theory analysis. Journal of Educational Administration, 49(3), 256-275. http://doi.org/10.1108/09578231111129055

Hallinger, P. (2009). Leadership for 21st century schools: from instructional leadership to leadership for learning. Hong Kong, China.

Hallinger, P. (2011). A review of three decades of doctoral studies using the principal instructional management rating scale: a lens on methodological progress in educational leadership. Review to Educational Administration Quarterly, 47(March 2010).

Hinton, P. R., McMurray, I., Brownlow, C., \& Cozens, B. (2004). SPSS Explained (1st ed.). Routledge.

Hohlfeld, T. N., Ritzhaupt, A. D., \& Barron, A. E. (2013). technology literacy significant? It depends on the model. Education Technology Research Development, 61, 639-663. http://doi.org/10.1007/s11423-013-9304-7

Hoy, W. K., \& Smith, P. A. (2007). Influence: a key to successful leadership. International Journal of Educational Management, 21(2), 158-167. http://doi.org/10.1108/09513540710729944

Jam, F. A., Akhtar, S., Haq, I. U., Rehman, M. A. U., \& Hijazi, S. T. (2010). Impact of Leader behavior on Employee Job Stress : Evidence from Pakistan. European Journal of Economics, Finance and Administrative Sciences, 21(21), 172-179.

Karaj, S. (2012). Teacher stress in Albania: examining the role of students' classroom deviant behavior and other factors in the school context. In 1st Albania International Conference on Education (AICE) (pp. 317-324).

Klenke, K. (2007). Authentic leadership: a self, leader, and spiritual identity perspective. International Journal of Leadership Studies, 3(1), 68-97.

Lydiah, L. M., \& Nasongo, J. W. (2009). Role of the headteacher in academic achievement in secondary schools in Vihiga District, Kenya. Current Research Journal of Social Sciences, 1(3), 84-92. Retrieved from http://maxwellsci.com/print/crjss/(3)8492.pdf

Mehdinezhad, V., \& Mansouri, M. (2016). School Principals ' Leadership Behaviours and its Relation with Teachers 'Sense of Self-Efficacy. International Journal of Instruction, 9(2), 51-60. http://doi.org/10.12973/iji.2016.924a

Mohd Hasril Amiruddin, Isma Atiqah Ngadiran, Fathin Liyana Zainudin, \& Norhayati 
Ngadiman. (2016). Tahap kemahiran generik pelajar Malaysia dalam proses pengajaran dan pembelajaran. Journal of Society and Space, 3(3), 111-121.

Mphale, L. M. (2015). Shared leadership practices: do secondary school heads in Botswana matter? Journal of Studies in Education, 5(2), 212-223. http://doi.org/10.5296/jse.v5i2.7307

Mullins, L. J. (2007). Management and organisational behaviour (8th Ed.). FT Management.

Nurul Izzah Abdul Samad, \& Zailina Hashim. (2010). Assessment of stress and its risk factors among primary school teachers in the Klang Valley, Malaysia. Global Journal of Health Science, 2(2), 163-171.

Othman Talib. (2015). SPSS Analisis data kuantitatif untuk penyelidik muda (2nd Ed.). Bangi: MPWS Rich Publication.

Pallant, J. (2011). SPSS Survival manual (4th Ed.). Everbest Printing.

Rasheed, M. I., Aslam, H. D., \& Sarwar, S. (2010). Motivational issues for teachers in higher education: A critical case of IUB. Journal of Management Research, 2(2), 1-24.

Schaubman, A., Stetson, E., \& Plog, A. (2011). Reducing teacher stress by implementing collaborative problem solving in a school setting. School Social Work Journal, 35(2), 72-93.

Siti Nor Afzan Kasiman. (2009). Ramai guru sakit jiwa. Kosmo Online, 22 March 2009. www.kosmo.com.

Taber, K. S. (2017). The use of cronbach' s alpha when developing and reporting research instruments in science education. Research in Science Education, 1-24. http://doi.org/10.1007/s11165-016-9602-2

Tahir, A. Q. (2011). Effectiveness of teaching stress on academic performance of college teachers in Pakistan. International Journal of Humanities and Social Science, 1(3), 123-129.

Urban, N., Manakova, N., \& Bielcheva, G. (2017). Socio-Economic and Regional Factors of Digital Literacy Related to Prosperity. Quality Innovation Prosperity, 1745, 124-141. http://doi.org/10.12776/QIP.V21I2.942

Walumbwa, F., Avolio, B., Gardner, W., \& Peterson, S. (2008). Authentic leadership: development and validation of a theory-based measure. Journal of Management, 34(1), 89-126. http://doi.org/10.1177/0149206307308913

Yukl, G., Mahsud, R., Hassan, S., Prussia, G. E., \& Prussia, G. E. (2013). An improved measure of ethical leadership. Journal of Leadership \& Organizational Studies, 20(1), 38-48. http://doi.org/10.1177/1548051811429352

Zainudin Awang. (2014). Research methodology and data analysis (2nd ed.). Subang Jaya, Selangor: UiTM Press. 